\title{
ChemCourse: Design of an ESP Course for Chemists and Chemistry Students
}

\author{
Olmedo Bula Villalobos \\ Universidad Estatal a Distancia, Costa Rica \\ Jenaro Alberto Díaz-Ducca \\ Universidad Estatal a Distancia, Costa Rica
}

\begin{abstract}
Resumen
Este artículo presenta el proceso de diseño de un curso de inglés para fines específicos (ESP) dirigido a estudiantes de química y químicos de la Escuela de Química de la Universidad de Costa Rica. Este proceso requirió un análisis para evaluar las necesidades profesionales y académicas de los estudiantes, sus intereses y carencias para crear un programa educativo que incluyera las cuatro macrodestrezas: habla, escucha, lectura y escritura. Además, una serie de estrategias de aprendizaje se consideraron en el proceso de diseño (parafraseo, negociación de significado, predicciones, escaneo, entre otras) para coincidir con las necesidades reportadas por los estudiantes. Basado en los resultados del análisis de necesidades, ChemCourse se diseñó para responder a sus requerimientos, intereses y carencias. Chem Course se implementó como un curso de ESP de quince semanas dentro de un enfoque fundamentado en el desarrollo de tareas para la enseñanza de idiomas. El contenido quedó divido en cinco unidades.
\end{abstract}

Palabras claves: enseñanza del inglés para químicos, química, inglés para fines específicos (ESP), análisis de necesidades, diseño de cursos

\begin{abstract}
This article presents the design process of an English for Specific Purposes (ESP) course addressed to chemistry students and chemists at the school of chemistry, University of Costa Rica. This process required a needs analysis to assess the students' academic and professional needs, wants, and lacks in order to create a course that included the four macro skills: speaking, listening, reading, and writing. This article presents the findings of the needs analysis. In addition, a set of learning strategies
\end{abstract}


were considered in the design process (paraphrasing, negotiation of meaning, predicting, scanning, among others) to fit the students' reported needs. Based on the findings of the needs analysis, ChemCourse was designed to respond to students' needs, wants, and lacks. Chem Course was developed as a fifteen-week, ESP course within a task-based language teaching (TBLT) approach. The content of the course was divided into five units.

Key words: English teaching foe chemists, chemistry, English for specific purposes (ESP), needs analysis, course design

\section{Introduction}

$\mathrm{M}$ astery of the English language is one of the most important assets for scientists nowadays. For speakers whose native language is not English, being up to date in their scientific field demands at least an instrumental knowledge of it. Mandatory for both speaking and writing, or just for reading purposes, no scientific education can be considered thorough nor complete without an intermediate level of proficiency of field-related vocabulary as well as reading or speaking skills.

In order to cope with the present demands of a globalized world, the Master's Degree Program in Teaching English as a Foreign Language (TEFL) at the University of Costa Rica, has been implementing the design and application of English courses as Final Graduation Projects (Practicum) for its graduate students for many years. These courses respond to the university population's needs in the form of English for Specific Purposes courses.

\section{Review of the literature}

A definition of English for Specific Purposes, hereafter referred to as ESP, and other key aspects are considered in this section. Dudley-Evans and St. John (1998) stress two features of ESP: 1. ESP teaching necessarily needs to reflect the professions' methodology that it serves - that is, the nature of the interaction between learners and teachers might be different from that in an EGAP class. 2. Language is absolutely paramount and it should be included as a relevant feature of ESP. DudleyEvans and St. John (1998) use absolute and variable characteristics when defining ESP. 1. Absolute characteristics: ESP is designed to meet specific needs of the learner; ESP makes use of the underlying methodology and activities of the disciplines it serves; ESP is centered on the language (grammar, lexis, register), skills, discourse and genres appropriate to these activities. 2. Variable characteristics: ESP may be related to or designed for specific disciplines. ESP may use, in specific teaching situations, a different methodology from that of general English; ESP is likely to be designed for adult 
learners, either at a tertiary level institution or in a professional work situation. It could, however, be used for learners at secondary school level; ESP is generally designed for intermediate or advanced students. Most ESP courses assume basic knowledge of the language system, but it can be used with beginners (p. 4-5). Likewise, Robinson (1980) defines ESP as the teaching of English to the pupils who have specific goals and purposes. For Hadley (2006, in Javid 2015), "ESP can be differentiated from general ELT by its concern with specialized language and practice" (p.18). This specialization clearly refers to pedagogical materials as well. As Javid (2015) has pointed out, original and adapted materials need to be used in ESP courses since "commercially available teaching material cannot cater for the specific needs of specific learners" (p.19).

Furthermore, needs analysis and evaluation are central to ESP. DudleyEvans and St. John (1998) state that "Needs analysis is the process of establishing the what and how of a course; evaluation is the process of establishing the effectiveness. Neither of these are one-off activities - they both need to be on-going" (p.121).

The essential stages in ESP can be summarized as follows, needs analysis, course and syllabus design, materials selection and production, teaching and learning, and evaluation (DudleyEvans \& St. John, 1998). It is clear that the needs analysis is absolutely significant to ESP. Dudley-Evans and St. John (1998) stress that "...needs analysis is the cornerstone of ESP and leads to a very focused course" (p. 122).

Likewise, motivation is essential when designing and teaching an ESP course like ChemCourse. In this regard, Strevens (as cited in DudleyEvans \& St. John, 1998) summarizes some of the advantages of ESP: Being focused on the learner's need, it wastes no time; it is relevant to the learner; it is successful in imparting learning; it is more cost-effective than General English (p. 9). Dudley-Evans and St. John (1998) point out:

... motivation in ESP has a profound effect on the question of how specific the course is. High motivation on the part of learners generally enables more subject specific work to be undertaken; low motivation, however, is likely to lead to a concentration on less specific work. Specialists in either academic or occupational contexts who need English for specific tasks will be impatient with an ESP course that does not address their difficulties with those tasks. (p. 10)

Finally, Dudley-Evans and St. John (1998) see the ESP practitioners as having five essential roles: 1 . Teacher 2. Course designer and materials provider 3. Collaborator 4. Researcher and 5. Evaluator. These are significant considerations of ESP.

\section{Needs analysis}

In the field of ESP, the main aspect required in order to design an ESP course is a needs analysis. According to Dudley-Evans and St. John (1998), one of the absolute characteristics of ESP is that it "is designed to meet specific needs of the learner" (p. 4). For the present investigation, since we were going to be working with chemists and 
chemistry students from the University of Costa Rica in an ESP environment, the first step was a careful needs analysis of our target population. In this sense, we incorporated fundamental aspects such as their tasks, needs, wants, and lacks (Hutchinson \& Waters, 1987). In order to have a complete view of the population and our job as course designers, we decided to perform a present situation analysis (PSA) by means of language proficiency (diagnostic) tests; a target situation analysis (TSA) by administering questionnaires and interviews; and a learning situation analysis (LSA) based on their language-learning background using questionnaires and interviews (Dudley-Evans \& St. John, 1998). This needs analysis report dealt with a target population of eighteen students, all Costa Rican, native speakers of Spanish, and students of chemistry in the University of Costa Rica. Their ages ranged between twenty-three and thirty-six years old. Two of them were students from the master's program in chemistry, and were also teachers and researchers. In general, the group was very homogeneous in terms of language proficiency $(66 \%$ intermediate, $22 \%$ high beginners, and 11\% low advanced).

\section{Data collection}

\subsection{First contact}

The contact professor was the coordinator of the School of Chemistry at the University of Costa Rica. An electronic mail message was sent, basically to introduce ourselves and arrange a formal meeting. Due to technical problems, initial contact via electronic mail was not possible with the contact professor. Finally, telephone contact was established. The first interview was held on March $14^{\text {th }}$ at the school of chemistry. The main purposes of this interview were to have a general view of the target population and the ESP course itself, and to start collecting data. The interview provided significant information in regards to the tasks, expectations for the ESP course and the organizational culture within the School of Chemistry. This interview was recorded for educational purposes. Regarding the first contact with our target population, potential students were sent an electronic mail message in which we introduced ourselves and provided a general overview of the process. The idea was also to corroborate students' electronic addresses (based on the professor's explanation that the vast majority of communications with students were done via electronic mail). Sixteen out of twenty-two students from the original list $(72.72 \%)$ responded to the message. With regard to the recruitment process, it is also relevant to mention that the contact professor had a meeting with the Association of Chemistry Students in order to offer this ESP course. The contact professor came up with an original list of twenty two students on a firstcome first-served basis. As it will be explained later on, this original list was modified later.

\subsection{Collection of materials}

During the interview with the contact professor, the importance of collecting authentic samples produced in English (materials professors and students use in class) was exposed. For the 
second meeting, our contact provided us with ten articles professors and students would probably use during the second semester (in different courses). The vast majority of materials were articles, basically because reading is one of the most relevant tasks chemistry students and chemists do. Besides, our contact professor provided us with two power point presentations that one of the professors at the school was planning to incorporate in one of his courses, which was in fact going to be taught in English. According to what he said to us during a short conversation, he used to teach that course in English due to the fact that most of the references and the content of the course were to be found in English. Next, three short videos (approximately two minutes each) were collected. The videos basically dealt with chemists, chemical, and chemical processes. All of these materials would provide significant input and scaffolding for students to perform the different tasks.

\subsection{Contact via electronic mail}

Messages via electronic mail were chosen as an effective way of communication basically for two reasons: students' organizational culture and time efficiency (with other stakeholders of the process included). The first contact with students, the administration of surveys (students and chemists), the appointments for the interviews and the appointments for the administration of the diagnostic test were prepared via electronic mail. Here an exception was done with the surveys of chemistry professors. According to the contact person, chemistry professors were normally so busy that it was unlikely that they would answer the survey via electronic mail. A more personal approach was required. Thus, our contact professor volunteered herself to talk to her colleagues about the survey and its importance for the process.

\subsection{Administering the survey}

4.4.1 Administering the survey to chemistry students

It is generally agreed that the target population constitutes the main source of information for a successful ESP course. Therefore, students were asked to complete a survey related to their experience with the language, wants, preferences, tasks, expectations, and difficulties. On April 1 ${ }^{\text {st }}$, we requested them to fill out the survey taking into account some basic guidelines: "Save the document in your PC, save it again with your information and send it as a reply to the sender's address." Students had a six-day window to complete the survey. The rationale behind this stage was the following, administering the survey first gave us important background about the target population. It would also give us the opportunity to address some aspects during the interview that might have been neglected in the survey itself, such as tasks and procedures (we had to deepen in these aspects during the interview, indeed). Refer to appen$\operatorname{dix} \mathrm{C}$ for a copy of this document.

\section{chemists}

4.4.2 Administering the survey to

For this part of the collection process, it was crucial to have the opinion and thoughts of a national authority in 
the field of chemistry. That is why we decided to support the needs analysis with the expertise of the Chemistry Body of Professionals. On April 2 ${ }^{\text {nd }}$, the General Procurator of the Chemistry Body of Professionals sent back a completed survey. Besides, recognized chemists and investigators from $\mathrm{Na}$ tional Institute of Biodiversity (INBio) also filled out the form. These surveys were related to common tasks chemists usually perform and suggestions for possible contents to be studied in an ESP course from a professional perspective.

\subsubsection{Administering the survey to} chemistry professors

Another important source of information was the Faculty of Chemistry. Our contact professor chose seven colleagues to complete the survey. As it was mentioned above, the contact professor volunteered herself to personally deliver and pick up professors' answers. The surveys were completed from April $5^{\text {th }}$ to April 10 ${ }^{\text {th }}$. Refer to appendix D for a copy of this document.

\subsection{Interviews with students and diagnostic test}

We administered the interview and the diagnostic test on the same day. The main reason for this was the point that applying the diagnostic test and the interview simultaneously would allow us to take the most out of students' input in one organized and efficient session. On April 9 ${ }^{\text {th }}$, students were cited to take the exam and the interview. It was overwhelming to see that only five students showed up, four from the original list (later we found out that students were going to have an important exam the following day). Based on the poor attendance, we decided to program a second session on April $11^{\text {th }}$. The electronic mail sent included a short note on the importance of going through all the steps of the process. Besides, the contact professor had an informal meeting with the students' association of chemistry representatives in order to emphasize the importance of this stage and the uniqueness of the course. The attendance for the second session was completely different, a total of sixteen students showed up, six from the original list. In addition, students who were not part of the original list were invited to complete the survey via electronic mail. Students were given a four-day window to fill them out. The following is the methodology applied, as students arrived, a greeting and small talk took place between students and the ESP practitioners basically to establish a friendly environment. Before asking students to complete the diagnostic test, we emphasized the purposes of the exam (to determine the students' level of proficiency and to provide crucial information, for example the lacks they felt needed to be incorporated in order to design an ESP course). This was done basically because some students evidenced the misconception that if they scored high in the test, they would have more possibilities to be accepted in the course. Next, students were asked to complete the diagnostic test individually. Then for the speaking part of the test, students had to pair up. Finally, we both interviewed students. At this point, we decided to modify the original list and use only the eighteen students who had completed the survey, the exam, and the interview 
for the purposes of the needs analysis. The rest of students who did not finish a stage in the process would become part of a waiting list for the future.

\subsection{Interview with the Director of the School of Chemistry}

On April $11^{\text {th }}$ at 8:30am, we had the opportunity to interview the Director of the School of Chemistry in his office. The main idea here was to extend the knowledge about the target population and his expectations for the ESP course. The interview confirmed the researchers' views on tasks, expectations, the organizational culture within the School, and possible contents to be studied. It is imperative here to acknowledge the Director's absolute commitment to this project. He considered it a top priority for the School. As soon the interview started, the Director was quick to establish a respectful and friendly environment to make the conversation much more fluid and thoughtprovoking. We recorded our conversation for future reference if needed.

\subsection{Class observations}

Two class observations were made with $2^{\text {nd }}$ and $3^{\text {rd }}$ year students on the week from April $7^{\text {th }}$ to April $11^{\text {th }}$. One of the observations included a regular class related to general theory. The second observation took place in a laboratory session. Some characteristics of these observations can be summarized here. Students regularly attended lessons in an auditorium (up to 150 students). There was little or no interaction among students and the professor; lessons were completely teacher-centered; students received significant amounts of theory and theoretical frameworks; students also attended laboratory practices in which they applied the theory and performed all kinds of experiments; students were expected to do research projects; students were asked to do extensive reading in English (their ability to read the language was taken for granted by chemistry professors). It is important to add that we did not design any particular instrument to collect data. We collected the information by means of note-taking about important events and situations we considered relevant.

\section{Description of the instruments used in the needs analysis}

\subsection{Survey for students}

This survey consisted of two parts. The first part included eleven multiplechoice items. The second part included eight open-ended questions. The survey was designed with the intention of including both objective and subjective items.

\subsection{Survey for professors and che- mists}

These surveys were constructed using six open-ended questions. When designing the surveys, we wanted to collect the information in an efficient and easy way for the participants. One relevant characteristic of the instrument was that the focus on the tasks students and future chemists had to perform in their professional life. 
5.3 Interview questions for the contact person and the school's director

We wrote a set of six items that worked as the backbone of the interview. The questions were related to expectations, tasks, and contents. They were designed to provide a flexible, open-ended framework for the interviews.

\subsection{Language instruments}

The language instruments were designed based on the tasks mentioned by students, the contact professor, and the chemists involved in the data collection process. The instrument provided students with general guidelines in Spanish. The main purposes of these guidelines were to promote confidence among students and to clarify the main purpose of the exam. The instrument started with a task related to reading. For the first part of the task, students had to read a twenty one-line paragraph about medical biochemistry. Then students had to read ten statements and decide whether the statements were true or false according to the text. Students had to write $\mathrm{T}$ for true statements and $\mathrm{F}$ for false statements. Five false statements and five true statements were constructed. We included a lot of synonyms and rephrasing in order to measure gist comprehension. For the second part of the task, students had to choose the main idea of the paragraph among four possible statements. The distractors were designed in a manner that students had to go through a careful analysis in order to answer. We decided to start the exam with a very familiar task for students basically to promote confidence. For the first part of the listening task, students were asked to watch a ninety-second video related to industrial chemistry. This video started with facts about chemicals (natural and synthetic). It also talked about how different chemicals behave under changing conditions. It also explained what chemists do (that is, study how chemicals affect each other and how they interact with the environment). It also mentioned the different fields where chemists work (energy development, medicine, and food processing). It also provided examples of products created through chemical research (fibers, drugs, paints, and cosmetics). Finally, it described the academic requirements in order to get a job as a chemist. This video was chosen because it was quite short, pertinent to their field, and addressed to English speakers at the intermediate level. Furthermore, it represented an authentic sample of technical speech. Students were told to watch the clip two times: the first one to become familiar with the material and the second one to take notes of relevant information. For the second part of the task, we asked them to decide if eight statements were true or false. Of these, three statements were true and five, false. We included plenty of synonyms and distractors. The third task was directed to writing skills. Students were expected to write a three-line electronic mail to a colleague or supervisor asking for bibliographical references about a familiar topic to students. We wanted to explore if students could write a message, their mastery of degrees of formality (register), and their communicative ability. This exercise was chosen since it stood as a frequent chore among students and chemists. Finally, the fourth task 
consisted of a speaking exercise in which students had to pair up and hold a three-minute discussion about the video. Students had a two-minute window to prepare the conversation. This, in order to produce a relatively spontaneous exchange but at the same time, allowing students to warm up and thus decrease their anxiety levels.

\subsection{Grading scales for establishing the students' level of proficiency}

As part of the present situation analysis (PSA), it is relevant to mention that a one-to-six scale for each macro skill was constructed to establish students' level of proficiency: Where 1 meant a low-beginner; 2, high-beginner; 3, low-intermediate; 4, high-intermediate; 5, low-advanced, and 6, high-advanced student. Before administering the test, the criteria to establish each of the levels for individual macro skills had been determined based on a rubric designed by the practitioners. Even though this was not an exhaustive test, the instrument gave us a valuable indication of the students' proficiency level.

\subsection{General view of the instruments}

The instruments intended to derive useful and meaningful information regarding the students' present situation and learning situation. Due to this, the intention was to collect information that could help the researchers determine not only the students' current proficiency level in general terms, but also their strengths and weaknesses in terms of the four macro skills: listening, speaking, reading, and writing in detail. Thus, our instruments needed to reflect real-life tasks, address the four basic skills, and provide opportunities for students to evidence their basic skills, strengths, and weaknesses. The tasks, therefore, were neither too easy nor too hard (authentic, varied, and designed to extract the key information easily for further analysis). As it turned out, these instruments met their objective and provided us with data that would direct and enrich the general class and materials design. In addition, several of the tasks and activities included in the test would be recycled later, expanded, and re-elaborated in order to address in class the tasks that students pointed out as the most relevant for both the academic and the professional environment.

\section{Profiles}

\subsection{School of chemistry}

The school of chemistry at the University of Costa Rica was founded in 1956 as a department and later it became an independent school in 1974. The faculty consists of forty two professors who specialize in the specific areas of oceanography, electro-chemistry, waste management, food processing, biochemistry, organic and inorganic synthesis and chromatography among others. Besides, the school's buildings include twenty three laboratories, two auditoriums, four warehouses for equipment and chemicals storage, a cold room, a water-distillation room, a computer room, and a maintenance shop.

\subsection{The chemistry program}

The Bachelor in Chemistry Program spans four years and includes 
theoretical and practical (laboratory) courses in areas such as physics, organic and inorganic chemistry, analytical chemistry, industrial chemistry, spectroscopy, and biochemistry. Considered a very demanding major by our contact professor, it prepares students to deal with the main branches of chemistry in the academic and professional fields. It is a very theoretical program compared to the chemical engineering's program, for example, which has a more industrial and commercial focus.

\subsection{Mission}

The programs of Bachelor and Licenciatura degree in Chemistry follow the School's mission statement. According to the information collected from our interview with the Director of the School such mission reads.

To contribute to the country's development and well-being through the application of chemical science and technology. [This will be achieved] by means of teaching, research, and community assistance. [In addition, the school] will prepare people who as professional chemists will be critical, creative, enterprising, ethical, and committed to the economic, social, and moral betterment of Costa Rican society.

This, in turn, is closely related to the School's vision, as the School's Director and the contact professor detailed in the interviews we held.

\subsection{Vision}

According to the Director, the strategic importance of chemistry and applied chemistry in the industrial and commercial areas of Costa Rica's economy cannot be denied. In order to further enhance the national industries' capabilities and potential, there is an enormous need of continuous updating and research. In that sense, the English language is a very important tool in order to read, quote, and submit articles to the world's most prominent chemistry journals, magazines, and associations.

As a result, students of the program need to cope with plenty of Englishwritten articles, manuals, indexes, and other academic corpora. This means that even if the students have not studied English before, they must achieve an instrumental use of the language appropriate enough to comply with the Program's academic requirements. Therefore, it is the Faculty's concern to provide students with the basic tools and skills that will allow them to read, comprehend, and professionally quote and apply chemistry-related information. Under such circumstances, a chemistry ESP course becomes an unexpected "blessing" for the School, in the Director's words. In short, chemistry students must and need to be able to read (at least) and master grammar, vocabulary, and technical terminology if they plan to succeed both academically and professionally in the future.

\section{Findings}

\subsection{General information about the population}

All but two of our prospective candidates were students of the third and fourth-year of the Bachelor's Degree in Chemistry. Two of them were graduate students from the Master's Degree in Chemistry and also worked as professors and researchers. They were 
all Costa Rican, and their ages ranged between twenty-three and thirty-six. There were seven women (39\%) and eleven men (61\%) for a total of eighteen students. Since our goal was language and not content assessment, all data derived was generalized for both undergraduate and graduate students as a single category.

\subsection{Proficiency level}

Their English proficiency level can be described as predominantly intermediate $(77 \%)$. These intermediate students were divided into $34 \%$ for low-intermediate, and 43\% for high-intermediate. In addition, 7\% scored as high-beginners and $16 \%$ as low-advanced. The group was very homogeneous, which facilitated enormously the teaching task, allow more complex activities, and particularly more production from the students. This concern about speaking was mentioned by most of them as their main want.

\subsubsection{Speaking}

Twelve out of eighteen students $(66.66 \%)$ scored at the intermediate level. This characteristic meant that we had to concentrate in developing more structured speaking tasks and drills. Besides, these students along with the two students (11.12\%) who scored as low-advanced could provide more input and an intrinsic motivation to the other four students (22.22\%) who scored at the high-beginner level. Some problems that students reported with the language can be summarized as: Subject-verb agreement represented a significant problem to these students. Sentences like: "People is... Chemists is... This investigation represent..." were very common. In general, intonation and pronunciation seemed to be minor problems. Difficulties with specific sounds like /v /and / e / were common and persistent.

\subsubsection{Reading}

Ten out of eighteen students (55.56\%) scored at the high intermediate level and seven out of eighteen students (38.89\%) scored as low-advanced. The fact that seventeen students (94.45\%) scored at the upper scale (high-intermediate and lo-advanced) might have been the result of extensive reading done by students in articles related to chemistry in English. Only one student (5.55\%) scored at the highbeginner level. Understanding specific details in a paragraph was the main problem for students when dealing with reading (first task of the reading section). All students failed, at least once, when they had to discriminate between false and true statements. Only two out of eighteen students (11.12\%) failed to identify the main idea of the paragraph (second task of the reading section).

\subsubsection{Listening}

Fourteen out of fifteen students (93.34\%) scored at the intermediate level. In contrast, only $5.5 \%$ scored as high-beginners and another $5.5 \%$ as low-advanced. In this aspect the group was again very homogeneous. This might allow us to focus on some learning strategies to improve listening skills, such as predicting, inferencing, and monitoring. In addition, all students had problems when taking notes 
of relevant information from the video (first task of the listening section). After analyzing the task, we concluded that even though the task was based on a listening activity, it included in fact a writing task too. Besides, there was an important possibility that students could have understood the text but had not considered the information from the video relevant enough in order to take notes. The second part of the listening exercise did assess students' comprehension of the text. Finally, in a real context, students attending a speech or lecture would have only one chance to listen to the information, thus note taking meant a vital strategy to be practiced and learned.

\subsubsection{Writing}

Seventeen out of eighteen students (94.45\%) scored at the intermediate level. Only one student (5.55\%) scored as low-advanced. This was also a very homogeneous skill among students. Although they evidenced problems with spelling, punctuation, and subject-verb agreement, for the tasks considered as central, students were able to communicate effectively in the target language.

\subsection{Tasks}

Based on Dudley-Evans and St. John (1998), it was decided to conduct a target situation analysis (TSA), that is, to establish objective needs. There was one point that needed to be clear before the data was analyzed and discussed. Since the course to be designed was basically an ESP course, it would have a professional and not an academic focus per se (that is, an English for Academic Purposes course - EAP).
However, the target population was composed by students and chemists who normally had roles in the academic environment at the university level. Therefore, that implied focusing on ESP but integrating EAP elements as well. Thus, we decided to determine the main tasks for both the academic and professional contexts, and based on that information, to select for teaching purposes only those that were common to both. In other words, the main intention was to get the best of both worlds and to develop meaningful tasks for both contexts. With this said, in order to keep a balance and a complete picture of both the academic and professional fields, we asked professors, chemists, and students for further details. So, professors were asked about the most important tasks chemistry students need to perform in English, whereas working chemists were asked for the main tasks professional chemists carry out. On the other hand, we interviewed students about both academic and professional tasks.

The main tasks in English pointed out by the professors were in order of importance: reading text books, articles, and manuals (90\%); speaking to customers and colleagues about a specific topic (60\%); writing e-mails (40\%); attending conferences and lectures, listening, and taking notes (40\%); problem solving (30\%); translating procedures and security sheets (20\%); reading labels and catalogues (20\%); making presentations about a specific topic or procedure (20\%); and writing reports about an experiment (10\%). On the other hand, students mentioned reading texts in English (100\%); speaking to customers about a product or service (72\%); attending conferences, 
listening, and taking notes (72\%); making presentations $(55 \%)$; reading labels and catalogues (44\%); writing e-mails (22\%); writing reports (22\%); writing articles (22\%); translation of procedures and security sheets (11\%); and problem solving (5\%).

As it was mentioned above, the learning context posed a difficult question when trying to design a "pure" ESP course. Due to the fact that the course was going be taught basically in an academic environment but within a professional framework, we decided to plan a course that would address both academic and professional elements as stated above. Indeed, this suggested an ESP course spiked with enough EAP elements. Because of this, we considered that the course should focus on skills, tasks, and activities common to both spheres: skills and tasks that students could perform at the university but that would also be helpful later on during their careers. Thus, the target situations were minimized to the common grounds they covered, in terms of skills and strategies, language contents and functions, structures, and vocabulary.

\subsection{Needs}

The needs where determined as a learning situation analysis (LSA). According to Dudley-Evans and St. John (1998), this should be based on "subjective and felt needs" (p.124). In general, students considered that speaking was the skill they needed to develop the most in order to communicate with customers (83\%). They also considered reading books, articles, and manuals (78\%); listening to conferences and lectures (72\%); and writing laboratory reports $(72 \%)$ as basic skills. In other words, they had in mind a holistic course that ought to combine the four macro skills and therefore, allow a balanced development of all four areas. It is pertinent to add that the order of importance of the tasks proposed responded not only to their needs, but also to their wants and expectations for the course. Keeping students motivated was one of our goals in order to prevent course dropout considering our course would not account for any academic credits. Consequently, the course outline should be appealing to students in terms of wants, preferences, and needs.

\subsection{Wants}

Students made clear the fact that they wanted an ESP course centered on speaking and listening as their two most urgent wants to be addressed. In order of importance, they listed speaking to customers (94\%), listening to lectures and conferences (83\%), writing laboratory reports (83\%), and reading books, articles, and manuals (72\%). As Hutchinson and Waters (1987) suggest, "objective and subjective views of needs (and wants) can, and do, conflict with a consequent de-stabilizing effect on motivation" (p.58). As a result, the course proposal had to cater for both needs and wants simultaneously. Thus, student motivation could be cultivated to prevent the usually high rates of desertion during ESP course implementation and practice, typical of previous courses for the master's practicum due to their "artificial" nature as courses with no academic credits assigned. 


\subsection{Lacks}

Lacks can also be perceived or objective, and felt or subjective (DudleyEvans \& St. John, 1998). Both types had to be established in advance then: objective lacks based on the PSA, and subjective lacks based on the information provided by the questionnaires. According to the students themselves, their main lacks were insufficient fluency (94\%); lack of self-confidence when speaking the language (89\%); problems with grammar (67\%); poor vocabulary (55\%); insufficient reading comprehension (55\%); limitations when writing, such as grammar or spelling (50\%); and poor listening comprehension (33\%).

\subsection{Reasons for studying English}

Students expressed what could be considered a very practical point of view. As it was said above, they expected a balanced course in terms of macro skills. Being young adults, most of them were very interested in developing their English skills, in order to look for a good (or better) job, to study abroad, or to work as professors. They considered English proficiency to be an indispensable asset for scientists and chemists in particular. In numeric terms, they mentioned, in order of importance, the following reasons for studying English: Reading books and magazines (78\%); communicating with people (72\%); finding a new job (67\%); taking international exams (61\%); studying or working abroad (61\%); travelling (55\%); watching movies and TV (39\%); and other reasons (22\%).

\subsection{Professional and academic background}

As it was indicated already, all of the participants were students at the School of Chemistry at the University of Costa Rica. They were either undergraduate students (83\%) or graduate students (17\%). The second group also worked as professors and researchers for the schools of Chemistry and Nutrition, whereas the first group consisted of students who also served as assistants for different professors from the School of Chemistry or as laboratory assistants. Due to this situation, their double role as students and researchers was going to be tapped by the ESP practitioners in order to enrich the classes based on their expertise and content knowledge.

\subsection{Language background}

Their target language background was very heterogeneous. Percentages were relative since many of them mentioned several categories. This variety in previous language contact was very positive in terms of the richness of potential class activities, and could even be considered one of the main causes for their assessed intermediate proficiency level as English users. According to the contact professor, chemistry students were expected to read in English since the first year of their major, independently of their previous language studies. In other words, they were pushed to develop at least the minimal operational reading skills, and to memorize vocabulary such as terminology for equipment, chemicals, and others. This point needed to be complemented with their (present) exposition 
to the language and their attitude towards English in that moment.

\subsection{Contact with the language}

As part of the PSA and the LSA, students had to respond to the question, Are you currently studying English? This was a key point, because this aspect could either facilitate or complicate the students' learning experience and the smooth implementation of the course. It would also influence the students' motivation since contact with the language outside the classroom was a very important aspect in learning reinforcement. Contrary to our original expectations, negative results were found. Most of the participants were not studying the language at that time, which could be discouraging in terms of extra exposition to English and practice beyond the classroom. This implied having to assign homework and extra-curricular activities to reinforce learning and promote further motivation and interest. On the other hand, when students were asked about the frequency of other English-related activities (such as watching TV or movies; reading books or articles; browsing the Internet; sending or receiving e-mails), results showed a significant level of daily contact with the language for leisure or entertainment activities. This could be used to our advantage to foster motivation and macro skill development in different manners. In this sense, this was a resource to be exploited in order to complement future language classroom activities.

\subsection{Attitude towards the language}

As one of the most important influences on the students' motivation, determining their attitude towards the target language was considered central in the LSA and PSA. In general terms, students reported an excellent attitude towards English, with the caveat (as it was established in the TSA) that for them, usage of English was basically instrumental and academic. Based on these results, we were very optimistic about the students' attitude, and their motivation inside and outside the classroom.

\subsection{Strengths}

As part of our LSA, we asked students to rank the four macro skills in terms of how easy they considered them. This would help us to determine what skills would also require more attention and reinforcement in order to be successfully developed. From the easiest to the most difficult, they mentioned reading (94\%); writing (50\%); listening (33\%); and speaking (17\%). In fact, these numbers confirmed what had been determined in the tests (PSA), where speaking and listening were the skills that scored the lowest and thus, that required more attention on the instructors' part.

\subsection{Weaknesses}

Next, students were asked to rank the four macro skills in terms of level of difficulty. From the hardest to the easiest, they mentioned speaking (72\%); listening (44\%); and reading (28\%). None of them included writing in their answers. Once again, these numbers 
matched what had been established during the tests (PSA).

\subsection{Activities students liked the most}

Since we also needed to determine the students' preferences in the classroom, we used a classification exercise based on a list of activities. Among the most liked activities they named oral conversations (100\%); listening to recorded conversations (83\%); working with texts (83\%); repeating written conversations (61\%); games (61\%); roleplaying (5,5\%); and making presentations $(5,5 \%)$. These results evidenced an interest in dynamic, communicative activities where oral production, listening, and text discussion (reading, speaking) were expected. Here it is important to add that since students considered making presentations a very important task, we decided at that moment that speaking in front of the class was going to be one of the main activities for classroom practice.

\subsection{Activities students liked the least}

Complementary to the previous point, knowing which activities students did not like was also relevant to lesson planning. Starting with the least liked activity, they mentioned repeating written conversations (39\%); games (33\%); listening to recorded conversations (17\%); and working with texts (16\%). Indeed, these answers emphasized the students' interest in participative and oral activities over more structured and traditional ones. The only exception to this apparent tendency was games that they probably found too infantile for university students and scientists. The use of games, however, was not necessarily discarded as a teaching activity beforehand.

\subsection{Students' expectations for the ESP practitioners and the course}

The conception students had of how their instructors should behave in the classroom was an aspect that we had to assess. This was formulated as an open-ended question; therefore answers were varied and even contradictory. Among their answers the following were reported: professors should speak in English at all times; professors should speak both in English and Spanish; professors should be patient; lessons should be dynamic and participative; professors should motivate students; classes should be student and not teacher-centered; error correction should be immediate and respectful; exams should contemplate all skills; professors should allow shy students to develop self-confidence; and lessons and contents should be authentic and adapted to Costa Rica's reality. It is important to add that students had high expectations of the professors and the lessons in terms of the instructors' mastery of language and different methodologies. Besides, materials should be interesting and the activities should aim at building students' confidence, learning, participation, and motivation. Regarding students' suggestions, six students pointed some such as focusing on technical vocabulary, developing participative activities, having lessons centered on the students, and offering a variety of activities in order to avoid class routine and monotony. 


\section{General description of course structure and syllabus}

Although the ChemCourse structure, syllabus, and implementation will be detailed in a future article, a brief glimpse of structure and target functions and contents follows. Based on the findings of the needs analysis, ChemCourse was developed to respond to students' needs, wants, and lacks. ChemCourse was a 15-week, ESP course within a Task-Based Language Teaching (TBLT) approach. Classes were taught on Mondays and Wednesdays from 5:00 p.m. to 6:45 p.m. at the School of Chemistry. It is also relevant to mention that ChemCourse was teamtaught. One professor was in charge of giving the lesson, while the other professor acted as an assistant teacher. The following are the units and tasks designed for the ChemCourse.

\section{Unit 1: How Can I Help You?}

Strategies, functions, and contents: Answering a customer's call following a pre-established protocol with appropriate manners; describing products and services to customers; setting up appointments to define sales terms; explaining a procedure to a customer.

\section{Unit 2: Dealing with Scientific} Literature

Strategies, functions, and contents: Reading and selecting articles applying both top-down and bottom-up approaches; interpreting new vocabulary from context; extracting, summarizing and explaining main ideas to colleagues; writing references and abstracts for academic papers; selecting sources and writing an abstract for a scientific article.

\section{Unit 3: At the Conference}

Strategies, functions, and contents: Note-taking during a lecture; asking questions of a lecturer in order to clarify ideas; summarizing, re-stating main ideas, and reporting them orally to a colleague; applying these skills a real lecture with guest speakers.

\section{Unit 4: At the Showcase}

Strategies, functions, and contents: Giving a presentation following the different stages for an oral presentation about a scientific process: Greeting, describing, presenting, summarizing, and closing; interacting with the audience in order to answer their questions; presenting a scientific process in front of an audience.

\section{Unit 5: Keeping in Touch}

Strategies, functions, and contents: Writing e-mails to providers asking for information about products and services; answering customers' e-mails about products and services; writing and replying to e-mails from customers and providers

In addition, a set of learning strategies were considered in the design process. These can be summarized as follows: Paraphrasing, negotiation of meaning, predicting, scanning, skimming, asking for clarification, schemata activation, using formulaic expressions, repetition, false questions, summarizing, brainstorming, making inferences, critical listening, guessing meaning from context, note-taking, active listening, reciprocation, topic expansion, communication breakdowns, and conversation management. 
Finally, different sets of original and authentic materials for the proposed units were designed and created. Refer to appendixes A and B for samples of these materials.

\section{Conclusions}

\subsection{General conclusions and impli- cations for course implementation}

Based on the information provided by the TSA, PSA, and LSA, the following general conclusions and their implications for the course design and implementation can be listed.

Population profile: Students represented a homogeneous population in terms of age, and professional and academic background. In terms of language proficiency, the group was fairly homogeneous: $77 \%$ of them were intermediate level students.

Skills: Their strongest skills were reading and writing; their weakest, speaking and listening.

Target tasks: The most important tasks reported were reading books, articles, or manuals, speaking to customers, listening to lectures, and making presentations in English.

Needs: Participants considered their most urgent needs speaking and reading. However, they requested all four skills to be practiced simultaneously in the classroom.

Wanted skills: Students wanted to develop mostly speaking and listening proficiency.

Lacks: They defined their most important subjective lacks to be scarce fluency, insufficient self-confidence, poor grammar, and limited vocabulary. Their most important objective lacks were speaking and listening (based on the PSA results from the diagnostic tests).

These pieces of information anticipated that the course had to be fairly communicative and interactive. Classes would be designed in order to cater basically for the same level of proficiency. In addition, there could be plenty of student-student scaffolding and correction whenever necessary.

Current language use: In terms of attitude, 89\% had a positive-excellent attitude towards English, whereas nobody expressed negative feelings and were daily exposed to the language for academic, professional, and recreational activities.

Target language use: Students had an instrumental interest in learning English basically for reading, communicating with people orally; finding a job, and studying abroad.

Classroom activities: They preferred oral conversations; listening to recorded conversations, working with texts; and repeating written conversations.

Expectations: They expected dynamic, participative, and communicative activities. Lessons had to be varied enough and promote motivation and learning. Regarding their instructors, they preferred patient, professional teachers who could create a relaxed learning environment based on respect, motivation, and authentic tasks.

These pieces of information indicated the nature of our future activities for the course: a wide variety of useful, meaningful, and realistic activities along with aspects relating to class management (pair and group work, constant feedback). As an additional asset, extra-curricular activities such as watching TV or movies, speaking to other people, reading, and browsing the Internet in English could 
be encouraged as complementary to classroom studies in order to foster learning and motivation.

\subsection{Limitations}

The following aspects were not considred in the needs analysis but needed to be addressed during the initial weeks of the course itself. They contributed to have a better understanding of the students' values and ideas, so as to promote classroom integration, motivation, and the students' contribution to class activities and contents.

Socio-economical background: What was the origin of the students? Did they come from urban or rural areas? What kind of education had they received, private or public secondary school? This would help to get familiarized with them, aiming at creating a more relaxed atmosphere in the classroom. Knowing their values and beliefs was very important in order to build future rapport.

Specialized field of interest: What branch of chemistry were they interested in? If they were working at the moment as laboratory or teacher assistants, what was their field of research? Were they satisfied with that?

Content collaboration: Definitely, the authentic texts provided were for the most part alien to our field of knowledge. In order to develop meaningful classes and activities, the assistance of one or several chemistry teachers was going to be required to keep a balance in terms of topics and types of materials. Furthermore, we would need to draw from the students' knowledge and expertise.

\subsection{Main challenges}

During the process of data collection and course design further difficulties were encountered. Although it must be admitted that the researchers had the unconditional support of the School's Director and the contact person, at first we found students to be only half-committed to the process. For example, during the first session of interviews and test-application, only five students showed up in two-and-a-half hours. In contrast, by the following session, and thanks to contact professor's intervention, sixteen students attended in more than two hours.

A final challenge that could be mentioned was some of the students' attitude. Although it was only two of them, these students showed a surprising reluctance and skepticism towards the course's potential. They questioned the methodology, the course's contents, and activities. Perhaps as part of the scientists' tendency to doubt evidence at face value, they might have been expecting a general English course or a simple conversational class. Besides, according to our contact, some of her co-workers expressed reserved positions regarding the course, because they wondered, "How can an English teacher teach a Chemistry course?" In all cases, we insisted on the fact that the course was going to be an ESP course, not a chemistry course in English. Although the topics to be discussed would be related to their field, the main aspect to be developed was English acquisition and oral and written strategies.

After a short discussion, we found that these were attitudes that might present some obstacles during the 
process of course implementation. We took them, nevertheless, as healthy examples of the cross-discipline experience that an ESP course implied. Far from worrying us, these comments helped us to take into consideration other aspects that actually enriched both the teaching and the learning experience during the coming months as the course developed.

\section{Bibliography}

Alderson, J.C. (2000). Assessing reading. Cambridge: Cambridge University Press.

Bailey, K. (2005). Practical English language teaching: speaking. New York: McGrawHill.

Bula, O., \& Díaz-Ducca, J. (2012). ChemCourse 2008: A teaching experience in the chemistry classroom. San José: Ediciones Quetzalcóatl, from http://lospobresdelatierra.org/jenaro/Chem Course2008/archivos/ Bula,\%20Diaz-Ducca\%20-\%20Chemcourse\%202008.pdf

Burns, A. (1999). Collaborative action research for English language teachers. Cambridge: Cambridge University Press.

Cook, V. (2001). Second language learning and language teaching. London: Arnold Publishers.

Delgado, C. (1992). Environment: a key factor in second language acquisition. Kañina, XVI (1), 185-193.

Doughty, C., \& Varela, E. (1998). Communicative focus on form. In $\mathrm{C}$. Doughty \& J. Williams (Ed.), Focus on form in classroom second language acquisition (pp. 114-138). Cambridge: Cambridge University Press.
Duddley-Evans, T., \& St. John, M. (1998). Developments in English for specific purposes. NY: Cambridge University Press.

Ellis, R. (2003). Task-based language learning and teaching. NY: Oxford University Press.

French-Allen, V. (1983). Techniques in teaching vocabulary. New York: Oxford American English.

Gass, S., \& Selinker, L. (2001). Second language acquisition: an introductory course. Mahwah, New Jersey: Lawrence Erlbaum Associates.

Graves, K. (2000). Designing language courses. Boston: Heinle\&Heinle Publishers.

Helgensen, M. \& Brown, S. (2007). Practical English language teaching: listening. New York: McGraw Hill.

Hutchinson, T., \& Waters, A. (1987). English for specific purposes. NY: Cambridge University Press.

Krashen, S.D. \& Terrell, T. (1983). The natural approach: language acquisition in the classroom. Hayward, California: Alemany Press.

Javid, C. (2015). English for Specific Purposes: Roles of learners, teachers, and teaching methodologies. European Scientific Journal 11, 17-22, from https://www.academia. edu/14531140/English_for_Specific_ Purposes_Role_of_Learners_Teachers_and_Teaching_Methodologies

Larsen-Freeman, D. (2003). Teaching language: from grammar to grammaring. Thomson-Heinle (Newbury House).

Leeman, J. (2003). Feedback in L2 learning: responding to errors during practice. In R. DeKeyser (Ed.), Practicing in a second language: perspectives from applied linguistics and cognitive psychology 
(pp. 37-63). NY: Cambridge University Press.

Long, M. (1998). The role of implicit negative feedback in SLA. Retrieved October 2, 2008, from http:// modernlanguage.co.uk/SLA/0005/ section13/index.html

Mitchell, R. \& Myles, F. (1998). Language learning theories. NY: Oxford University Press, Inc.

Nunan, D., \& Lamb, C. (1996). The self-directed teacher. Cambridge: Cambridge University Press.

Philp, J. (2003). Noticing the gap. Retrieved October 2, 2008 from http://itesjl. org/links/studiesinSLA/5687ujy87. html

Quesada, A. (2009). Issues for effective distance learning: a challenge inonline education. Revista de Lenguas Modernas, 11, 345-362.

Richards, J. \& Renandya, W. (2002). Methodology in language teaching: an anthology of current practice. NY: Cambridge University Press.

Richards, J. \& Rogers, T. (2001). Approaches and methods in language teaching. NY: Cambridge University Press.

Robinson, P. (1980). ESP (English for Specific Purposes). NY: Pergamon Press Ltd.

Sheen, Y. (2004). Corrective feedback and learner uptake. Retrieved October 2, 2008, from http://www.lsj. com/tesol/correctivefedback/pre0558kju1a.html

Wallace, M. (1998). Action research for language teachers. Cambridge:

Cambridge University Press.

Yin, R. (1984). Case study research: design and methods. Newbury Park, CA: Sage.

\section{Appendix A}

Handout \#0203a

ChemCourse - Unit \# 2 Dealing with scientific literature

INSTRUCTIONS: Study and analyze the following verbs. Classify them according to the three different ed endings. Use the rule previously studied.

-associated-identified-discovered-localized-dissected-accomplished-separated-required-

$$
\text { /id/ /d/ /t/ }
$$

Handout \#0203b

\section{ChemCourse - Unit \# 2 Dealing with scientific literature}

INSTRUCTIONS: Read the title of the article and predict its content by providing your own ideas. Be ready to report to the class. Use the useful expressions chart. 


\section{Identification of the Sex Pheromone of the German Cockroach, Blattellagermanica}

Useful expressions

For me...

I (think) believe that...

To me...

This reading deals with...

The article is about...

The pheromone suggests that...

Blattellagermanica is...

Probably this article...

The main idea is...

Handout \#0203d

ChemCourse - Unit \# 2 Dealing with scientific literature

INSTRUCTIONS: Prepare an oral summary (5 minutes max.) of the article. Write your ideas in the space provided. Be ready to report to the class.

* Greet the audience.

* Omit unnecessary words and phrases.

* Do not turn your back to the audience.

* Watch you posture.
* Include all important ideas.

* Do not read.

* Keep regular eye-contact.

* Focus on pronunciation (ed endings).

\section{Appendix B}

\section{Handout \#0208b}

ChemCourse - Unit \# 2 Dealing with scientific literature

\section{Paraphrasing}

Paraphrasing can be defined as restating in your own words what a writer (or speaker) has presented already. The ideas are the same but the form in which they are expressed changes.

Original: "NASA researchers have resparked interest in the original carbon nano-onions, considering them as potential additives for aerospace applications..."

Paraphrase: "Scientists from NASA have renewed their interest in the original carbon nano-onions, due to the fact that they could be used as components in the aerospace industry..." 
INSTRUCTIONS: In pairs, read the following extracts from an article and paraphrase them. Be ready to justify your reasons.

"Carbon is a singular chemical element with a unique ability to join together forming a wide variety of fascinating molecules, ranging from a few carbon atoms to long complex chains.

This ability has allowed the creation of numerous new materials and molecules of interest for a very diverse range of applications..."

\section{Handout \#0208c}

\section{ChemCourse - Unit \# 2 Dealing with scientific literature}

INSTRUCTIONS: For the 60-Second Science podcast about nanotech paper, comment with your classmates and instructor the following questions. Use the phrases below to express your opinion. Remember: Think fast, it's a Blitz Task!

a. What did you find the most interesting about the content?

b. How is the content relevant to your major/field?

c. Express your comments or professional opinion on the subject

d. Glossary: photosynthesis - electrolysis - alkaline - heat - fuel cell - harsh catalyst - phosphate - cobalt - electrode - electrolyzers

\begin{tabular}{|l|l|}
\hline \multicolumn{2}{|c|}{$* *$ Useful Ways to Express your Opinions ** } \\
\hline - What do you think? & - I think that... / I believe that... \\
\hline - Is that right? & - I am (not) sure about that. \\
\hline - Do you agree with me? & - I agree. / I disagree (with you.) \\
\hline - Excuse me, but... & - I don't think you're right. \\
\hline - This is relevant / important because... & - They could have talked about... \\
\hline - This (also) relates to... & - They could have (also) mentioned... \\
\hline
\end{tabular}

\section{Appendix C}

\section{Cuestionario para los estudiantes de química}

Nota: la información aquí suministrada es estrictamente confidencial y será utilizada para diseñar un curso que responda específicamente a sus necesidades. Por favor responda en forma veraz las siguientes preguntas. Este cuestionario le tomara aproximadamente 10 minutos. ¡Muchas gracias por su colaboración!

INSTRUCCIONES: marque con una "X" la opción u opciones que apliquen para su caso.

1. ¿Ha estudiado usted inglés antes? 
Sí

No

2. Si su respuesta es afirmativa, indique el lugar y el número de meses. Marque todas las que aplican en su caso.

\begin{tabular}{|l|l|}
\hline \multicolumn{1}{|c|}{ Lugar } & \# de meses \\
\hline a. En el colegio & \\
\hline b. En la universidad & \\
\hline c. En un instituto & \\
\hline d. En otro país, indique cuál & \\
\hline e. Por cuenta propia (libros, métodos, CD, internet, cursos a distancia, etc.) & \\
\hline f. Otra, indique & \\
\hline
\end{tabular}

3. ¿Cuál es su actitud hacia el idioma inglés? Marque todas las que aplican en su caso.
a. Me fascina
b. Me gusta
c. No me gusta
d. No tengo ningún comentario
e. Otra, indique

4. ¿Está estudiando inglés actualmente?

Sí

No

Si su respuesta es afirmativa, indique el lugar. Marque todas las que aplican en su caso.
a. En la universidad
b. En un instituto
c. Por cuenta propia (libros, métodos, CD, internet, cursos a distancia, etc.)
d. Otra, indique

5. ¿Por qué estudia inglés? Marque todas las que aplican en su caso.

a. Porque quiero viajar

b. Porque lo necesito para conseguir trabajo

c. Porque quiero comunicarme con personas de otra cultura

d. Porque quiero leer libros, revistas y artículos en inglés

e. Porque quiero ver películas y televisión en inglés

f. Porque quiero hacer exámenes internacionales en inglés (TOEFL, etc.)

g. Porque quiero estudiar o trabajar en un país angloparlante

h. Otra, indique

6. ¿Con cuánta regularidad practica lo siguiente fuera del aula? 


\begin{tabular}{|l|l|l|l|l|}
\hline & Muy a menudo & A veces & Muy poco & Nunca \\
\hline a. Ver TV en inglés & & & & \\
\hline b. Hablar con gente en inglés & & & & \\
\hline c. Leer libros en inglés & & & & \\
\hline d. Leer artículos en inglés & & & & \\
\hline e. Usar internet en inglés & & & & \\
\hline f. Mandar correos en inglés & & & & \\
\hline g. Otra, indique & & & & \\
\hline
\end{tabular}

7. De acuerdo a las tareas académicas y profesionales que usted realiza o realizará, ¿cuáles son las habilidades del idioma inglés que usted necesita dominar?

LLectura Escritura Conversación Escucha

8. De acuerdo a las tareas académicas y profesionales que usted realiza o realizará, ¿cuáles son las habilidades del idioma inglés que a usted le gustaría dominar?

Lectura

Escritura

Conversación

Escucha

9. ¿Cuáles de las siguientes habilidades del idioma inglés son más fáciles para usted?

Lectura Escritura Conversación Escucha

10. ¿Cuáles de las siguientes habilidades del idioma inglés son las más difíciles para usted?

Lectura

Escritura

Conversación Escucha

11. Considere las siguientes actividades de clase. Indique su preferencia de acuerdo a este parámetro:

Sí: Sí me gustaría realizarlas en clase.

No: No me gustaría realizarlas en clase.

\begin{tabular}{|l|c|c|}
\hline \multicolumn{1}{|c|}{ Actividad } & Sí & No \\
\hline a. Trabajar con un libro de texto y lecturas & & \\
\hline b. Practicar conversaciones orales & & \\
\hline c. Practicar conversaciones escritas & & \\
\hline d. Hacer juegos & & \\
\hline e. Escuchar diálogos grabados & & \\
\hline f. Otra, indique & & \\
\hline
\end{tabular}


12. ¿Cuáles son las cinco tareas más relevantes (que requieren inglés) que realizan los estudiantes de química en el aula?
a.
b.
c.
d.
e.

13. Seleccione la tarea más relevante de las que mencionó y explique en detalle cómo se hace y cuáles procedimientos e interacciones implica.

14. ¿Cuáles son las cinco tareas más relevantes (que requieren inglés) que realizan los químicos en el campo laboral?
a.
b.
c.
d.
e.

15. Seleccione la tarea más relevante de las que mencionó y explique en detalle cómo se hace y cuáles procedimientos e interacciones implica.

16. ¿Cómo debe ser un buen profesor de inglés (forma de dar la clase, corregir errores, etc.? Explique.

17. ¿Cuál es su mayor dificultad al aprender inglés? Explique.

18. ¿Cómo prefiere trabajar en el aula: en grupos, en parejas o individualmente? 
19. Sugerencias para el curso:

\section{Appendix D}

\section{Cuestionario para los profesores de química}

Nombre: Curso que imparte:

Nota: la información aquí suministrada es estrictamente confidencial y será utilizada para fines académicos exclusivamente. Por favor responda en forma veraz las siguientes preguntas. ¡Muchas gracias por su colaboración!

1. ¿Cuál es la razón principal por la cual los estudiantes de química y los químicos necesitan aprender inglés? Explique.

2. ¿Cuáles son las cinco tareas más relevantes (que requieren inglés) que realizan los estudiantes de química en el aula y los químicos en el campo laboral?
b.
c.
d.
e.

a.

3. Seleccione la tarea más relevante de las que mencionó y explique en detalle cómo se hace y cuáles procedimientos e interacciones implica.

4. ¿Cuáles son los temas y contenidos que deberían estudiarse en un curso de inglés para estudiantes de química y químicos graduados? 
5. ¿Cuáles actividades ha observado usted como las más efectivas para el aprendizaje de los estudiantes? Marque todas las que considere pertinentes.

Clases magistrales

Exposiciones

Trabajo individuales
Trabajos en grupo

Prácticas de laboratorio
Reportes Otros:

6. Sugerencias: 